U.S. Department of Agriculture

Animal \& Plant Health Inspection Service

Wildlife Services

August 2016

Wildlife Damage Management Technical Series

\section{Double-crested}

Cormorants
Brian S. Dorr

Research Wildlife Biologist USDA-APHIS-Wildlife Services National Wildlife Research Center Mississippi State, Mississippi

Kristi L. Sullivan

Extension Associate

Department of Natural Resources

Cornell University

Ithaca, New York

Paul D. Curtis

Associate Professor

Department of Natural Resources Cornell University

Ithaca, New York

Richard B. Chipman

Rabies Management Program Coordinator

USDA-APHIS-Wildlife Services

Concord, New Hampshire

Russell D. McCullough

Regional Fishery Biologist

New York State Department of Environmental Conservation

Bureau of Fisheries

Albany, New York

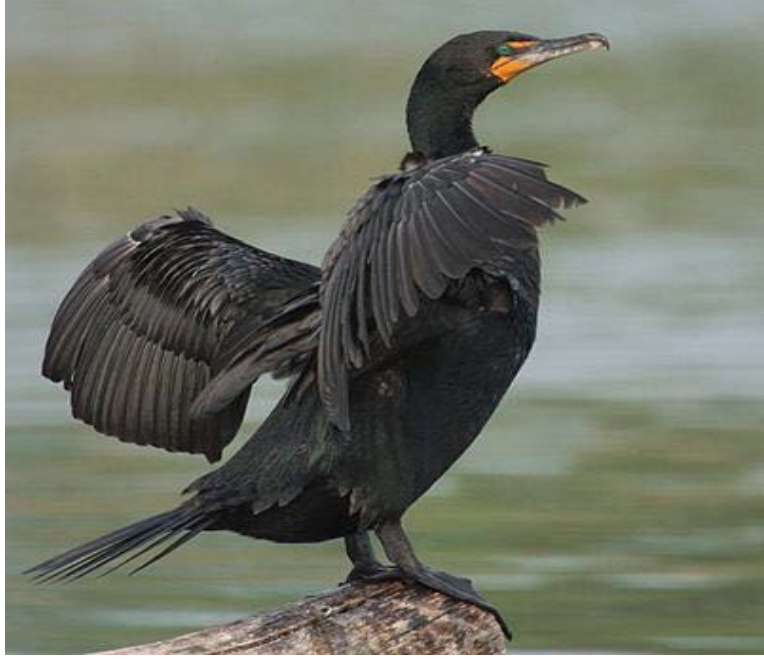

Figure 1. Double-crested cormorant (Phalacrocorax auritus)

\section{Quick Links}

\begin{tabular}{|ll|}
\hline Human-Wildlife Conflicts & 1 \\
Damage Identification & 3 \\
$\underline{\text { Management Methods }}$ & 4 \\
$\underline{\text { Economics }}$ & 9 \\
$\underline{\text { Species Overview }}$ & 9 \\
$\underline{\text { Legal Status }}$ & 13 \\
$\underline{\text { Glossary \& Key Words }}$ & 15 \\
$\underline{\text { Resources }}$ & 16 \\
$\underline{\text { Appendix }}$ & 17 \\
\hline
\end{tabular}

\title{
Human-Wildlife Conflicts
}

\section{Fisheries}

The history of conflict between doublecrested cormorants (Figure 1) and human interest in fisheries is long and convoluted. Following a low point in the 1970s, populations of cormorants expanded in North America, as did concerns about impacts on fisheries. By the late 1990s, natural resource agencies in 27 states reported losses of free-ranging fish stocks to cormorants. Agencies in 10 states, ranging from the Southwest to the Northeast, considered cormorant predation to be of moderate to major concern to fishery management. 


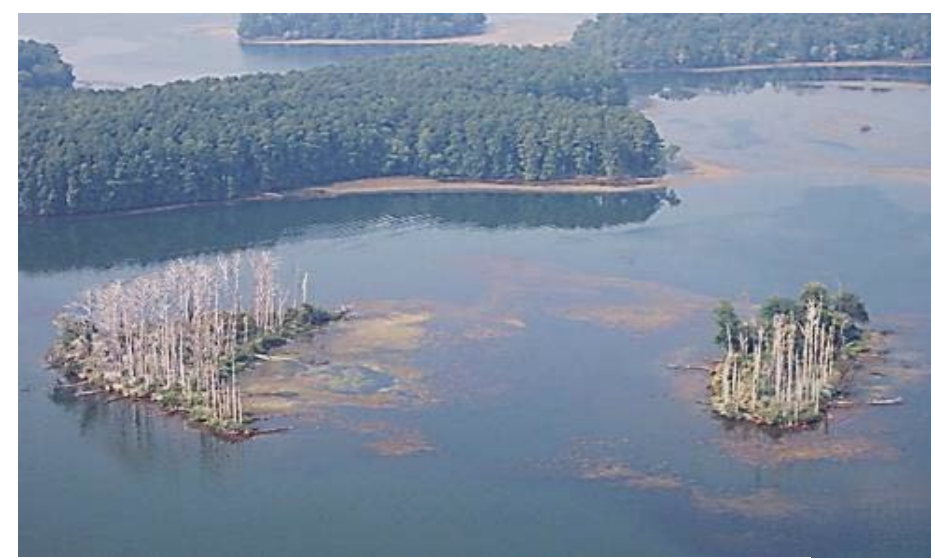

Figure 2. Impacts of breeding double-crested cormorants on trees in Guntersville Lake, Alabama

Overall, double-crested cormorants are not major consumers of commercial and sportfish species. However, exceptions have been recorded at specific sites with documented impacts on local fisheries (see Damage to Fisheries section). Cormorants often congregate and can have significant local impacts where high concentrations of fish occur, such as stocking release sites, private fishing ponds, aquaculture ponds, reservoirs, spawning sites, and other areas.

\section{Landscapes}

Double-crested cormorants can have a significant impact on vegetation at breeding sites through normal nesting activities. Their guano is acidic and can change soil chemistry, killing ground vegetation and irreversibly damaging nest trees. Cormorants also destroy vegetation directly by stripping leaves and small branches from trees for nesting material. At times, the weight of the birds and their nests can even break branches. Loss of trees can lead to increased erosion, particularly on sand spits and barrier beaches.

In one example on Little Galloo Island in Lake Ontario, all of the trees died over time due to a combination of defoliation and guano. Damage to vegetation can occur relatively quickly after cormorants move into an area. For instance, in the St. Lawrence estuary, cormorants on several islands caused irreversible damage to trees in less than 3 years. After cormorants started nesting on Young Island at Lake Champlain in 1982, all but one nesting tree was killed by 1996.

In some cases, cormorant colonies have significantly affected rare plant communities. For example, the islands in western Lake Erie are home to rare Carolinian woodlands with stands of Kentucky coffeetree. Large cormorant colonies there could threaten the continued existence of these plants.

In the Green Bay area of Wisconsin, vegetation on several islands has been impacted by cormorants. Habitat changes have allowed other ground nesting species to occupy these islands, which can perpetuate damage even in the absence of cormorants. In the southeast on Lake Guntersville, Alabama, cormorant breeding colonies have also caused nearly complete loss of trees on once forested islands (Figure 2).

The interactions between colonial water-birds and vegetation are natural occurrences that have taken place throughout history. Succession of plant and avian communities caused by these changes may not be negative from a conservation or management perspective. However, in human-altered ecosystems where alternative habitat is limited or unavailable, cormorants can affect the persistence of plant communities and other wildlife species that rely on these habitats.

The strong odor of droppings near roosts and nesting areas, along with the loss of vegetation, may reduce nearby property values. Tourists attracted to the natural beauty of waterfront areas may view the areas as unattractive once cormorants take up residence. On a local scale, decreasing property values and reduced tourism and recreation may cause economic losses for area residents and businesses that rely on income from tourism.

\section{Human Health and Safety}

Humans should avoid direct contact with excrement from wildlife, including droppings from cormorants. Cormorants can present a bird-strike hazard when their populations and nesting or foraging habitats occur in or near the flight 
paths of planes. Although only 4 to 5 incidents with cormorants are reported per year in the Federal Aviation Administration wildlife-aircraft strike database, damage can be severe due to the cormorant's large size and weight.

Newcastle disease, a viral disease that can affect all bird species, was first recognized in double-crested cormorants in the St. Lawrence River Estuary, Quebec, in 1975. In 1992, double-crested cormorants in 7 states died from the disease. This widespread epidemic affected cormorants from the interior population, causing juvenile mortality rates ranging from 10 to $90 \%$. By the late 1990 s, outbreaks had occurred in cormorant populations across North America. The frequency of outbreaks in cormorants seems to be increasing since 2003, although the cause is unknown. Symptoms include lethargy, twisting of the head and neck, lack of muscular coordination, tremors, incomplete paralysis, and weakness of the legs and wings.

Possible transmission of Newcastle disease from freeranging, wild birds to poultry is a concern, although there have been only 2 or 3 reported incidents worldwide possibly linking double-crested cormorants and other related waterbird species to outbreaks in domestic poultry. No extensive mortality to Newcastle diseases has been reported in other wild birds that share habitat with infected double-crested cormorants. Infections identical to those found in cormorants, however, have been isolated from American white pelicans and ring-billed gulls.

People also can contract Newcastle disease. Symptoms, including conjunctivitis, fever, headache, and malaise usually are mild and last 3 to 4 days. Newcastle disease is transmitted through bird guano, or by humans who have been in contact with infected birds. Therefore, people working with double-crested cormorants should take measures to prevent infecting other birds, wild or domestic. After handling cormorants, disinfect hands, footwear, and equipment, and wash all clothing.

\section{Nuisance Problems}

Cormorants may foul docks and navigation devices with feces while roosting or drying their wings when foraging.

\section{Damage Identification}

\author{
Damage to Fisheries
}

Flocks of foraging cormorants are easy to identify and often are reported by local anglers. Damage typically is reported by anglers as reduced catch or by aquaculture producers as reduced harvest. In recreational fisheries, state agencies also may report declines in sport fish numbers during monitoring efforts.

Cormorant diet studies often have concluded that cormorants have little impact on recreational or commercial fishing because these fish make up a small percentage of cormorant diets. Diet studies by themselves, however, typically do not measure impacts to fish populations. Many diet studies are conducted during periods when sportfish are not normally consumed by cormorants and after sportfish populations have declined, which can contribute to low estimated consumption rates. Cormorants also are opportunistic predators whose diet varies considerably with local prey availability. For example, investigators found that the percent of sport and commercially significant species in the diet of double-crested cormorants feeding at a Wyoming river varied from less than $1 \%$ to $93 \%$. On Lake Champlain in Vermont and New York, diet studies conducted before and after establishment of alewives showed a shift in diet from primarily yellow perch to alewife. At Rice Island in the Columbia River estuary, salmonids, some of which are federally-listed as threatened or endangered, were the most important prey of double-crested cormorants.

Cormorants typically prey on specific size and age classes of sportfish. When they consume a large percentage of specific age-class fish, they may limit recruitment, even when consumption of sportfish is a relatively small percentage of total diet. This is particularly important if sportfish populations are low. In addition to rigorous diet studies, it is important to have information on the number of cormorants foraging, fish abundance, and age-specific fish mortality to fully understand the impacts of cormorants and effects of management if implemented. For example, in the Eastern Basin of Lake Ontario, 
researchers found a 36\% reduction in 3- to 5-year old smallmouth bass resulted in an estimated $78 \%$ decline in recruitment to fishable stock from 1976 to 1998. In Brevoort Lake, Michigan, cormorant consumption of walleye, although less than $6 \%$ of the total diet, represented $55 \%$ of a year-1 walleye age class. Successive years of cormorant predation on a small number of age cohorts potentially can cause recruitment bottlenecks of harvestable fish age and size categories.

Researchers have studied the walleye population, recreational fishery, and cormorant diet at Oneida Lake, New York, for decades. Based on over 40 years of fish population data, they concluded that cormorant predation likely was a significant source of sub-adult walleye mortality that negatively affected recruitment to the fishery.

In recent years, several large studies of fishery-cormorant interactions have been conducted. In the eastern basin of Lake Ontario, declines in 2 important recreational fish species, smallmouth bass and yellow perch, coincided with increases in cormorants. A program to manage cormorants was implemented in 1999 that included egg-oiling, nest destruction, culling of breeding adults, and prevention of new colonies. These efforts resulted in a $50 \%$ decline in nesting numbers and a large reduction in numbers of fish fed to chicks. Smallmouth bass and yellow perch populations have remained consistently above low levels observed during peak cormorant nesting years. Cormorant management likely contributed to increased smallmouth bass and yellow perch abundance, but fish populations also may have been influenced by other contributing factors such as a recent increase in invasive round goby in the cormorant diet. In the Les Cheneaux Islands area of Michigan, a similar cormorant management effort using egg-oiling to limit reproduction and lethal control of adults on breeding colonies was implemented to improve the yellow perch fishery. Monitoring indicated that the yellow perch population improved to historical levels, an improvement that has been sustained for more than 5 years. In Brevoort Lake, Michigan, a program of nonlethal harassment supplemented by limited lethal take of spring migrating cormorants to limit foraging on spawning walleye resulted in increased walleye survival and abundance. The above cases independently provide evidence that cormorants were impacting local fisheries and that management can improve fish stocks. The strength of evidence varies for each location, however, and in most cases results are confounded by other factors

The above management outcomes reflect situations in which long-term fishery data indicated cormorant predation was an issue; expertise and institutional commitment also supported multi-year management, research, and monitoring programs. Impacts of cormorants on fisheries typically are highly variable due to site-specific conditions. Aquatic systems are extremely complex, and the impacts of any single predator species are difficult to demonstrate with a high degree of certainty.

In addition, cormorants and other birds can serve as potential vectors of diseases in fish. For example, cormorants likely are involved in the transmission of whirling disease in trout, but their role in the spread of disease is not understood.

\section{Management Methods}

A key to damage prevention is the integration of multiple methods that are complementary; a single technique used in isolation seldom is successful. Habitat management is the foundation of integrated wildlife management because it provides long-term protection and enhances the effectiveness of other control techniques, such as frightening devices.

It is important to monitor the situation and apply control methods before or as soon as damage begins and only if damage is likely to be substantial. Money often is wasted when control techniques are implemented after substantial damage has been inflicted or the overall damage inflicted is minor and the cost of control exceeds the losses.

\section{Habitat Modification}

Nest trees can be removed or destroyed with the hope that adult birds will either leave the area or fail to rebuild and re -nest successfully that season. Removal of nest trees may 
discourage cormorants from nesting in new areas, especially early in the nesting season. Removal of trees may not be a viable option where aesthetic or habitat impacts are a concern.

\section{Fisheries Management}

Hatchery-raised fish are particularly vulnerable when large numbers are released in a lake at once, or when spawning behavior or natural movements, such as runs of salmon smolts, concentrate fish in small areas. Release fish at night so they have time to disperse before cormorants begin feeding in the morning. In lakes, release fish in deep water, rather than from shore to reduce predation. In streams, stock fish early in the season before cormorants return from their wintering grounds. Fish also are vulnerable to cormorants when harvest methods congregate them in enclosed areas that cormorants can access. Use exclusion and frightening devices to reduce predation when stocking or harvesting fish.

\section{Exclusion}

Physical barriers such as netting or grid wire systems can prevent cormorants from preying on fish in hatcheries or aquaculture ponds (Figure 3 ). Nets are effective when their edges extend to the ground surrounding the pond to prevent cormorants from walking under the netting and into the water. While physical barriers can be effective, they can be impractical and cost may be prohibitive for large ponds. In some instances, space may be limited for net supporting structures, and netting may interfere with machinery needed for daily operations.

Overhead-wire systems make it difficult for cormorants to land on and take off from ponds. Although these systems are effective at preventing large flocks from landing, individual birds often learn to fly between the lines, or land on levies and walk into the pond despite the wires. Wire systems also can protect nesting colonies of other waterbirds. Along with gulls, cormorants can out-compete common terns for favored nesting islands.

Wires suspended above nesting colonies of terns can enhance success and productivity by discouraging larger

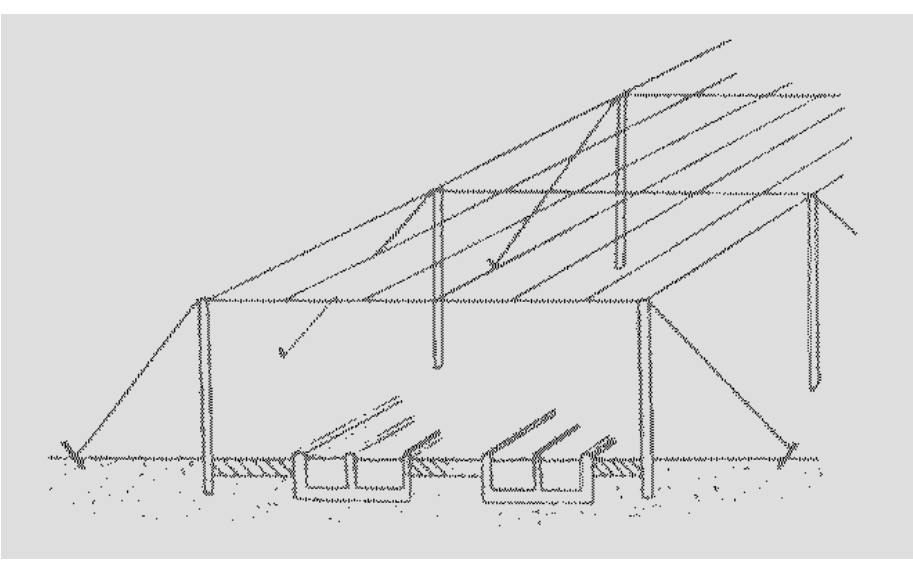

Figure 3. Overhead wires can be useful in protecting hatcheries from bird predation.

birds from nesting. This method effectively reserves nesting space for common terns until they are able to establish and defend a colony. Wires may reduce access to people and present hazards to non-target species such as swallows, osprey and bald eagles.

Ropes with plastic floats, sometimes called bird balls, are a less expensive and less labor-intensive alternative to wire systems. Floating ropes can be strung parallel to each other about 50 to 55 feet apart. The success of both wire systems and floating ropes depends on the availability of alternative foraging areas nearby. Birds that are able to find other food sources easily are more likely to be deterred.

Changes in aquaculture practices may reduce depredation by cormorants and other fish eating birds. For example, in split-pond production systems (Figure 4), production of fish occurs in a much smaller area of the pond, making harassment of birds more effective and the use of physical barriers feasible.

\section{Frightening Devices}

Harassment, or scare tactics, applied in an integrated and consistent fashion can discourage cormorants from using specific sites. Birds can be hazed at fish hatcheries and aquaculture facilities, as well as roosting and nesting sites on larger bodies of water. Harassment is most effective when the birds are not nesting or before birds have become habituated to a location. Cormorants learn quickly, 


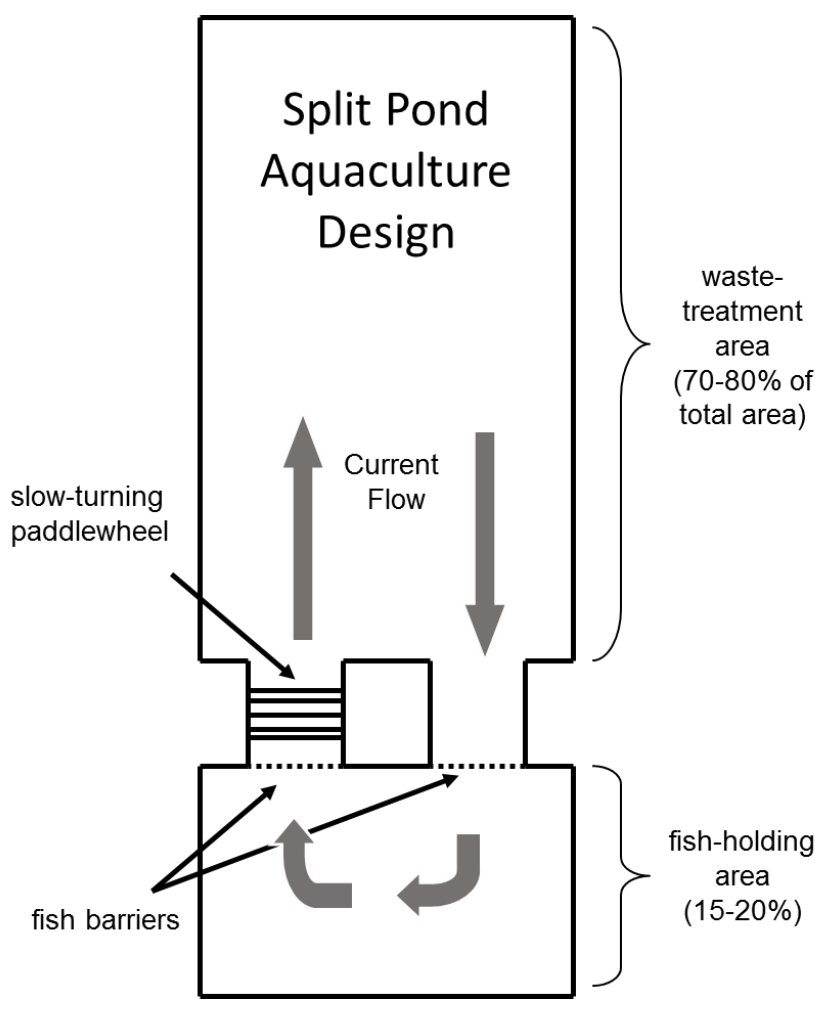

Figure 4. Aquaculture practices, such as split pond catfish aquaculture designs, may reduce bird depredation on fish stocks.

so frightening devices often do not deter the birds for long. For best results, use a variety of techniques and change the location and combination of devices frequently.

\section{Auditory}

Devices that make noise, including pyrotechnics such as shell crackers, screamers, whistling or exploding projectiles, bird bangers, propane cannons, and live ammunition, have been used to disperse cormorants with varying success. Live ammunition, while technically not a pyrotechnic, often is the least expensive and most readily available form of frightening device. Other methods may be more effective, but take care to avoid injuring or killing cormorants and other protected species.

Hand-held lasers have been used successfully to disperse roosting cormorants and are most effective in low light conditions (twilight, nighttime, overcast skies). In addition, lasers are silent and can be used to move cormorants with minimal disturbance to non-target species. The regular presence of humans may frighten cormorants from smaller aquaculture or hatchery facilities, as well as from roosting sites and potential colonies. Encourage frequent human activity near valuable fish stocks to reduce depredation on fish.

\section{Visual}

Visual harassment techniques (e.g. scarecrows, human effigies, and balloons) also have been tried with varying degrees of success. Mylar ${ }^{\circledR}$ tape (Figure 5 ) suspended on stakes near roosting and loafing sites has been effective in reducing cormorant use of areas. In addition, boats can be used to chase cormorants and successfully disperse roosts and flocks from ponds and larger bodies of water.

Use of limited lethal control with harassment techniques may improve the effectiveness of harassment and is sometimes necessary to prevent acclimation to non-lethal methods.

Further effort in evaluation of novel non-lethal methods is being pursued. Researchers in Canada used a tethered raptor with some success to disperse nesting cormorants from a colony site. Drones are being investigated for their potential use in dispersing nesting cormorants from bridges, and to harass birds on ponds.

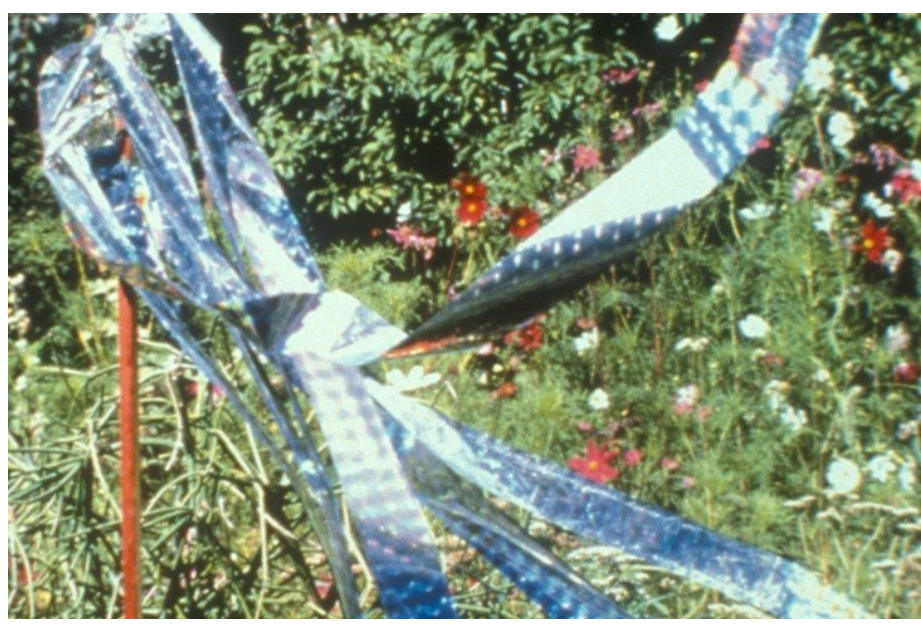

Figure 5. Irri-Tape ${ }^{\mathrm{TM}}$ is Mylar-style tape used to frighten cormorants. 


\section{Repellents}

None are registered.

\section{Nest Removal and Treatment}

Nests can be removed or destroyed to limit reproduction and disperse nesting birds. Nest destruction is relatively labor-intensive, although it can be practical on smaller colony sites. It requires more effort in colonies that are already established. High-pressure water sprays have been used to destroy cormorant nests in trees. Nest removal may be useful for discouraging cormorants from nesting in new areas, especially if nests are destroyed early in the nesting season. To be effective, control must be repeated throughout the nesting season, and likely on an annual basis. Nest removal may shift cormorants to other locations where they may cause continued conflicts.

Egg addling can be used to prevent or reduce population growth, and may be useful for eliminating colonies at specific locations, especially if combined with other harassment or population reduction methods. Eggs can be oiled (Figure 6) by spraying with food-grade corn oil to prevent the exchange of gases through the shell, causing asphyxiation of the embryo. Eggs also can be addled by vigorously shaking or puncturing them with a sharp small rod. The benefit of egg addling over destroying eggs is that cormorants will continue to incubate the eggs and are less likely to attempt to re-nest. Management strategies that include egg-oiling are best suited to situations where the presence of cormorants can be tolerated, and rapid population reduction is not the goal. Cormorants often re-nest, so some reproduction may still occur if persistent effort is not applied. In some states, a pesticide applicators license may be required for oiling eggs.

Any technique that involves egg or nest destruction, or removal of cormorants likely will require federal and state permits or come under the authority of federal Aquaculture or Public Resource Depredation Orders.

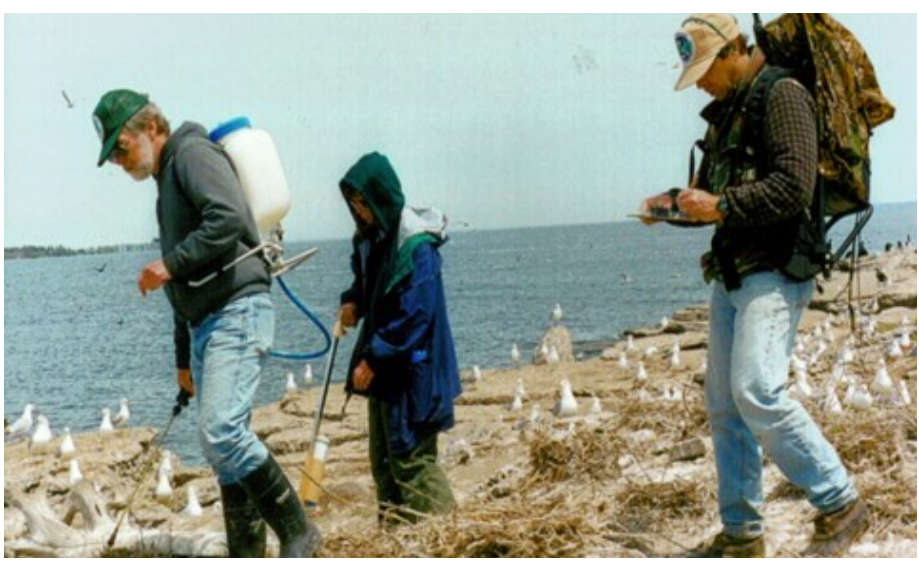

Figure 6. Spraying oil on eggs in double-crested cormorant nests. The typical 3-person team has a backpack sprayer for food grade corn-oil, a person marking each nest with paint, and a data recorder.

\section{Fertility Control}

Currently no methods of surgical or chemical sterilization or immuno-contraception are available or practical for controlling cormorants.

\section{Toxicants}

None are registered.

\section{Trapping}

\section{Net Traps}

Spring-loaded net traps (clap net traps) can be used to capture nesting colonial waterbirds. Place dummy eggs in a nest and set the trap so that it closes over a bird that comes to the nest. Monitor the nest from a nearby blind so the trapped bird can be removed from the trap quickly to prevent injury. After the bird is caught and euthanized or released, put the actual eggs back in the nest. Other lessused capture techniques for cormorants at their nests include swim-in traps, rocket and cannon nets, and net launchers.

\section{Foot-hold Traps}

Place modified foot-hold traps at nests to capture adult birds during the breeding season in April and early May. 


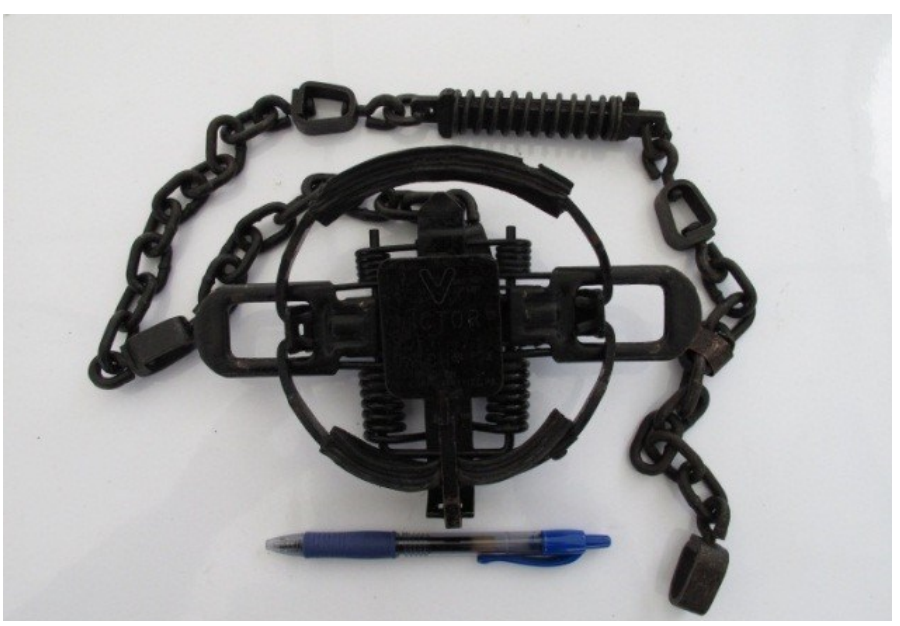

Figure 7. No. 3 padded-jaw foothold trap. All 4 springs should be removed and replaced with 2 springs suitable for a No. 1.5 paddle-jaw foothold.

Use a No. 3, padded-jaw, foot-hold traps that has been modified by replacing factory coil springs with weaker No. 1.5 trap springs (Figure 7). Replace the trap chain with aircraft cable and a shock cord to minimize injury to trapped birds. Place dummy eggs in the nest during trapping (Figure 8). After the bird is caught and euthanized or released, put the actual eggs put back in the nest.

\section{Spotlights and Long-handled Nets}

At night, cormorants can be disoriented by shining a spotlight on them and captured with a long-handled net on foot or by boat. This method works best on dark nights with low ambient light.

\section{Shooting}

Shooting allows for relatively rapid reduction in cormorant numbers. Shooting can be most effective on breeding colonies, where large numbers of birds congregate each day. Open-water shooting and removal at night roosts also can be used to protect specific sites. Cormorants respond well to both floating and silhouette decoys, which can make shooting more effective and reduce non-target take (Figure 9).

Use a 12-gauge shotgun with No. 4 or 6 non-toxic shot size. Qualified agency personnel may also use suppressed 0.22-

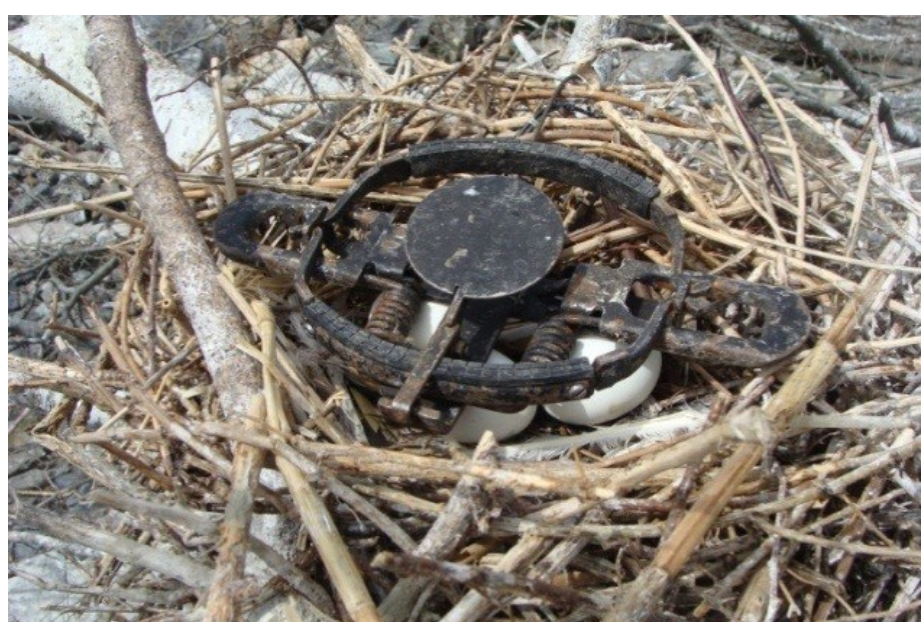

Figure 8. No. 1.5 foothold trap in place over dummy eggs in a cormorant nest.

or 0.177-caliber rifles on nesting colonies. Shooters should be knowledgeable in waterbird identification to prevent killing non-target species. Shooting adult cormorants not only removes birds, but also harasses the remaining birds. Shooting can be combined with pyrotechnics to enhance the effectiveness of non-lethal control options. Remove carcasses by hand and dispose of them using approved methods.

\section{Handling}

\section{$\underline{\text { Relocation }}$}

Capture and relocation is not practical or effective, and thus is not recommended.

\section{Translocation}

Capture and translocation usually is not practical for cormorant management. Cormorants often move to different roost or nesting locations due to management activities such as hazing. While translocation from, for example, a hazed site is desirable, translocation to other sites can have an unpredictable outcome (i.e. positive, negative, or neutral). 


\section{Euthanasia}

Shooting is the most common method of euthanasia for double-crested cormorants. If a bird requires euthanasia while in hand, cervical dislocation is the most practical technique.

\section{Disposal}

Check your local and state regulations regarding carcass disposal. Recovered banded cormorants should be reported by calling 1-800-327-BAND.

\section{Economics}

Cormorants may be managed whenever their damage justifies the granting of the permits necessary to control them. Adult cormorants eat approximately 19 ounces of food per day, so local impacts of large flocks on fisheries can be substantial. Although cormorants frequently are blamed for reductions in fish harvests, this is not always substantiated. Sometimes other factors, such as pollution, invasive species, and habitat loss may be the primary factor or contributing factors in the decline of fisheries.

\section{Species Overview}

\section{Identification}

Cormorants are slender birds with webbed feet and a long sturdy beak with a hook at the end. Six species reside in North America, namely the double-crested cormorant (Phalacrocorax auritus; Figure 1), great cormorant (Phalacrocorax carbo), neotropic cormorant (Phalacrocorax brasilianus), red-faced cormorant (Phalacrocorax urile), pelagic cormorant (Phalacrocorax pelagicus), and Brandt's cormorant (Phalacrocorax penicillatus). This chapter will focus on the double-crested cormorant, which is the most numerous and widely dispersed of the species.

\section{Physical Description}

The double-crested cormorant (Figure 1) is a long-lived, colonial-nesting waterbird native to North America. It usually is found in flocks, and sometimes confused with geese or loons when on the water.

Double-crested cormorants have black plumage tinted with a greenish gloss on the head, neck, and underside. In breeding plumage, tufts or crests of feathers appear for a short time on either side of the head of adult birds, giving them their name. Their black bills are slender and cylindrical with a hooked tip and sharp edges. They have black, webbed feet set well back on their body, a long curving neck, orange facial skin, and an orange throat pouch like their pelican relatives. Some 1- to 2-year-old juvenile cormorants have grey or tan plumage on their neck and breast.

Double-crested cormorants are 29 to 36 inches long with a wingspan of 45 to 52 inches. They and weigh about 4 to 6 pounds. On average, double-crested cormorants live about 6 years, but a few over 22 years have been reported.

\section{Range}

The double-crested cormorant is found in association with water bodies across the continental U.S. and along the southern coast of Alaska (Figure 10).

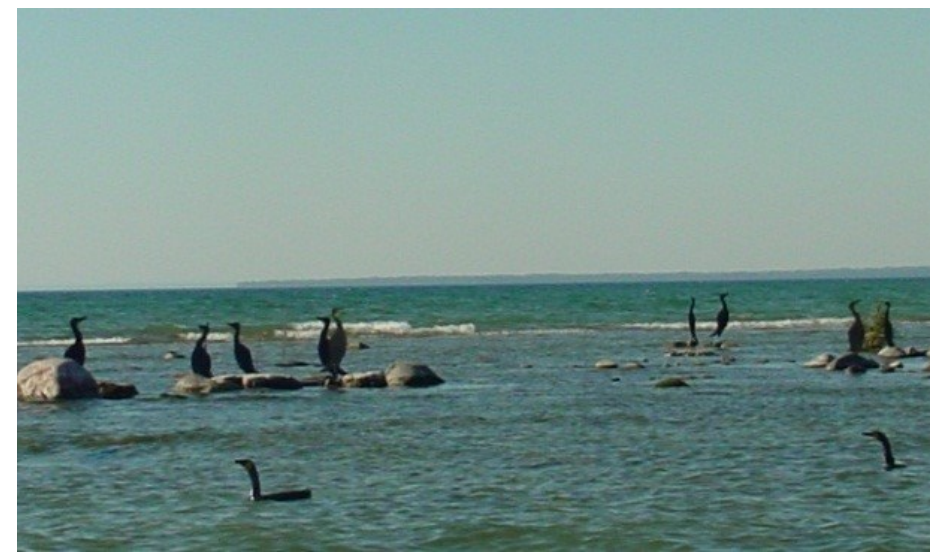

Figure 9. Floating and silhouette decoys used in double-crested cormorant control. 


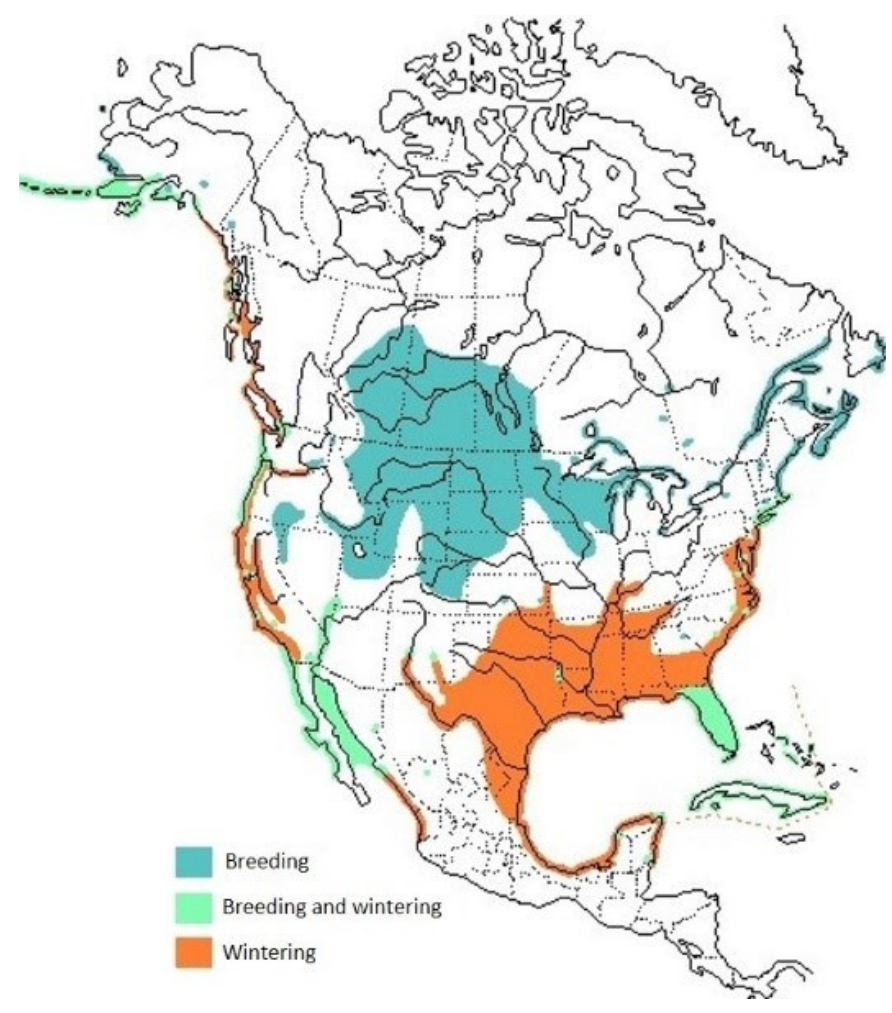

Figure 10. Range of double-crested cormorant.

The breeding range of the cormorant is divided into 5 geographic areas: Alaska, the Pacific coast, southern U.S., interior U.S. and Canada, and northeast Atlantic coast. A small number of double-crested cormorants breed in the southeastern U.S. Populations in the interior U.S. and Canada, northeast Atlantic coast, and southern U.S. have been increasing and expanding their range since 1980 .

\section{Tracks and Sign}

Cormorants have webbed feet, but rarely leave tracks on the rocky substrate used for nesting. The most obvious signs are visual observations of flocks of birds feeding or resting, guano deposits, and their coarsely constructed stick nests in trees or on the ground.

\section{Voice and Sounds}

Cormorants usually are silent, but make hoarse, grunting, and guttural calls at breeding colonies and roost sites.

\section{Reproduction}

Cormorants are monogamous and breed in colonies ranging from several to over 10,000 pairs (Figure 11). Most double-crested cormorants return to the same location to breed year after year. Young cormorants often return to the colony where they hatched or to nearby areas to breed. Most cormorants are sexually mature by their third year, but a small number breed a year sooner.

Normally cormorants have only 1 clutch per year, although they readily re-lay if eggs are taken by predators or destroyed. Clutch sizes range from 1 to 7 , with 4 eggs being most common. Both sexes incubate the eggs and incubation lasts 25 to 28 days. Embryos are tolerant of cold but not of heat. Hatchlings are altricial and weak, but growth is rapid, with chicks reaching about $90 \%$ of fledgling mass in 24 days. Young birds can walk by 3 weeks and begin to fly at 6 to 8 weeks. Fledglings are completely independent about 10 weeks after hatching.

\section{Nesting Cover}

Males typically show up first, unpaired, on the breeding grounds and establish territories. Pairs form and begin constructing elevated platform nests composed of twigs, branches, and other plant materials in April to May. These nests often reach a height of 12 to 20 inches and may be re-used in subsequent years.

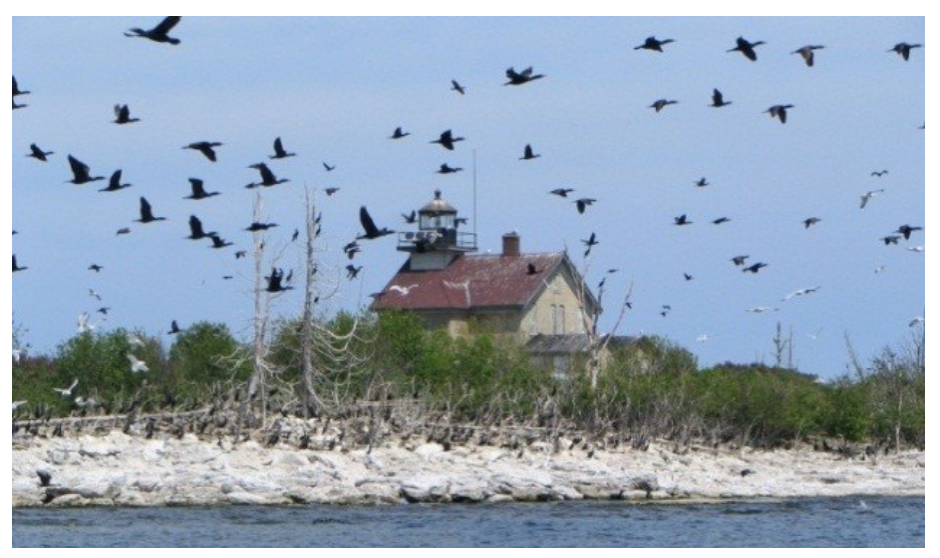

Figure 11. After a dramatic decline from the 1950s to 1970 s, numbers of double-crested cormorants and breeding colonies have increased. 
Cormorants typically use islands from 1 to 15 acres, with larger colonies often at more remote locations. Cormorants nest in trees, on cliffs, or on the ground (Figure 12). After years of repeated nesting in the same location, their guano often kills trees and other vegetation.

Cormorants are attracted to nesting sites of other colonial waterbirds and may compete with gulls, terns, egrets, herons, and some waterfowl (Figure 13). Cormorant guano deposited under nest trees can kill understory vegetation important for nesting black-crowned night herons and other tree-nesting species. At West Sister Island National Wildlife Refuge in Lake Erie, which supports one of the largest great blue heron colonies in the Great Lakes, heron numbers have declined annually since the double-crested cormorant arrived in 1992, presumably due to a combination of nest site competition, loss of nesting sites, and increased in human activity.

\section{Mortality}

Double-crested cormorants commonly live more than 8 years and occasionally 22 years or more in the wild. Estimated first-year mortality is over $50 \%$, but survival greatly increases to over $80 \%$ annually for older birds. Eggs and chicks are taken by a variety of predators, particularly gulls and crows. Disturbance to colonies can cause extensive chick mortality due to predation and exposure. Adults have few predators, with the exception of eagles. Humans also affect cormorants and a substantial number are killed by entanglement in fishing gear.

\section{Population Status}

In 2005, the continental population of cormorants was estimated between $1,080,800$ and 2,163,600, which is similar to the estimates of 1 to 2 million individuals in the 1990s. A dramatic population decline occurred between the 1950s and 1970s, caused by human persecution and chemical contamination from DDT. Cormorant numbers began to rebound in the mid-70s after DDT was banned. Pollution control lowered the concentrations of toxic contaminants in the bird's food. Food became more abundant throughout their winter and summer ranges (e.g. alewife in the Great Lakes, stocked lakes, and catfish aquaculture in

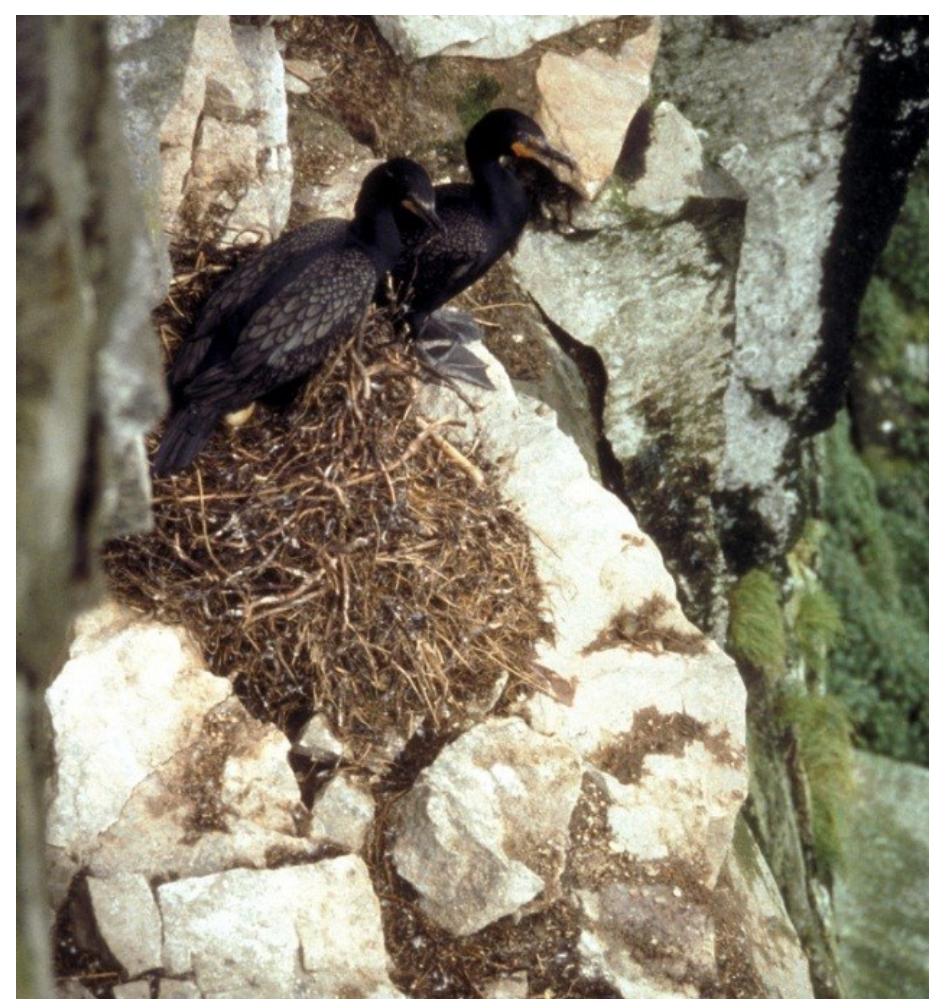

Figure 12. Double-crested cormorants nesting on a cliff.

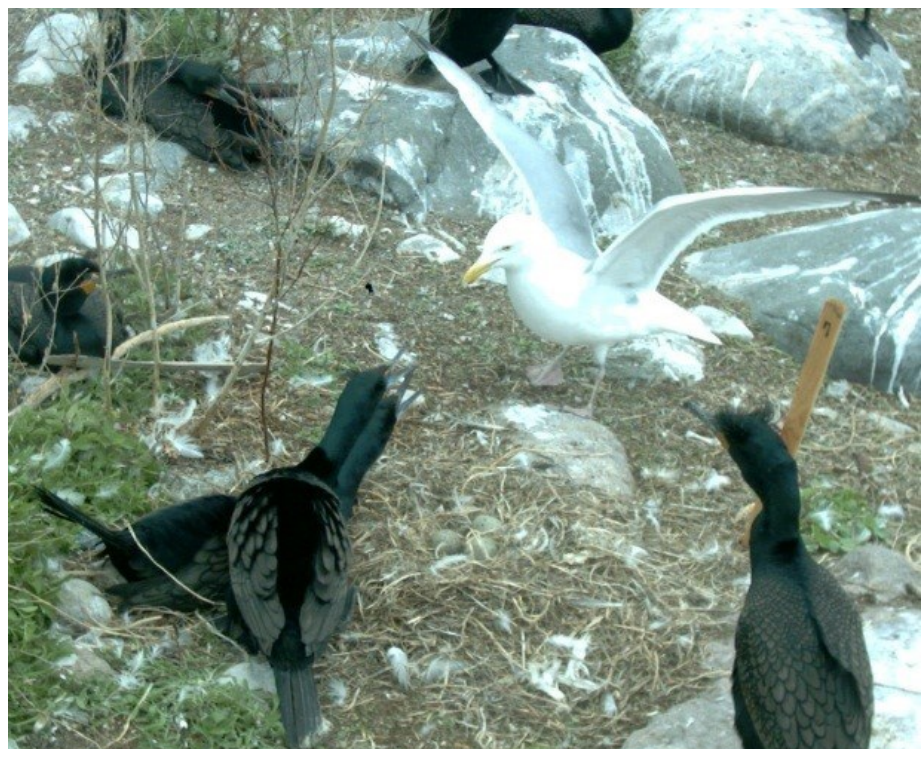

Figure 13. Double-crested cormorants competing with a herring gull for its nest site. 
the Southeast), and cormorants were given protection by both federal and state laws.

The interior meta-population generally is considered the largest, with close to half a million individuals. In the Great Lakes region, the number of cormorants increased an average of 29\% per year from 1970 to 1991, after which population growth slowed. The Great Lakes metapopulation currently is stable or declining and may have reached carrying capacity in the North Channel of Lake Huron and other areas. The U.S. Fish and Wildlife Service (USFWS) reported that this decline was more pronounced in the US Great Lakes, where more management occurs, relative to the Canadian Great Lakes.

\section{Habitat}

During the breeding season, double-crested cormorants inhabit lakes, ponds, slow-moving rivers, lagoons, estuaries, and open coastlines. They need suitable nesting sites with feeding areas nearby. Cormorants may nest on the ground, on steep cliffs, or on rocky or sandy islands, but they prefer to nest in trees. Nesting trees and structures usually are located near water, on islands, in swamps, or along tree-lined lakes. Cormorants typically choose live trees for nesting, although the trees often die within 3 to 10 years because of the significant accumulation of guano deposited on and beneath them.

Outside of the breeding season, cormorants use a variety of habitats including marine islands and coastal bays. Cormorants establish nighttime roosts and daytime resting or loafing areas on sandbars, rocky shoals, cliffs, offshore rocks, utility poles, fishing piers, wires, channel markers, pilings, and trees near their fishing grounds.

\section{Behavior}

Cormorants are expert divers, with webbed feet, streamlined bodies, and feathers that hold water and reduce buoyancy. They typically dive 8 to 25 feet, although depths of up to 85 feet have been recorded. After feeding, cormorants characteristically dry their feathers by perching with their wings outstretched (Figure 14).
Double-crested cormorants of the Atlantic coast and interior populations are seasonal migrants. They leave the Northeast in September and migrate south along coastlines and river valleys. The 2 primary migration routes are down the Atlantic coast and through the Mississippi and Missouri River Valleys to the Gulf Coast. Cormorants return to their northern breeding grounds in late March or April.

Home ranges of cormorants are highly variable and can be very large. Breeding season home ranges of cormorants marked with satellite transmitters ranged from 7 to over 11,583 square miles. Winter home ranges show similarly large variation in size, ranging from 31 to 6,753 square miles.

\section{Food Habits}

Double-crested cormorants feed almost exclusively on fish (Figure 15). They typically prey on small (less than 6 to 8 inches), bottom-dwelling, or schooling "forage" fish, especially those that are most abundant and easiest to catch. This includes fish such as alewife, gizzard shad, yellow perch, sculpins, and sticklebacks.

Diets of cormorants vary considerably from site to site and throughout the year. Their ability to catch fish depends on several factors, such as distribution, relative abundance, behavior, and habitat. Their diet often reflects the number and type of fish present in a given area at a given time.

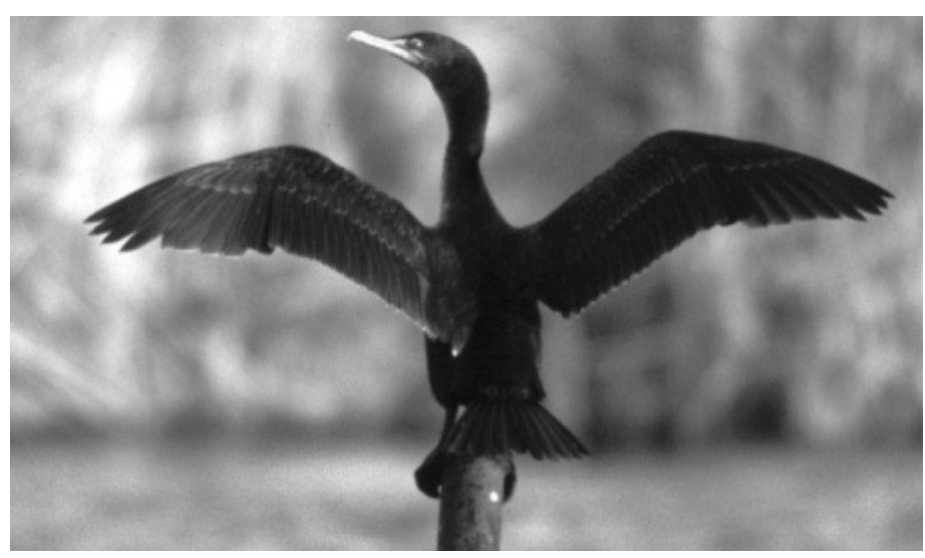

Figure 14. Double-crested cormorants perch on trees, rocks, buoys, and other objects that overhang or project from water. 
Typically, cormorants feed during the day in water less than 25 feet, within a few miles of the shore and their breeding colony. To capture fish, cormorants dive below the surface and pursue prey underwater. Dives may last from 17 to 34 seconds or more. The birds sometimes swim with their heads submerged, searching for prey. They grasp prey in their bills and sometimes swallow fish underwater. Cormorants swallow large fish or those that are difficult to handle (e.g., eels or spiny fish), at the surface. At times, they throw their prey into the air, catch it, and swallow it head first. Cormorants typically forage individually, but may gather into feeding flocks of hundreds of birds, especially when preying on small schooling fish.

Adult cormorants feed regurgitated food to their nestlings. To feed very young chicks, an adult will arch its neck, take the head of the chick into its mouth, and regurgitate a semi -liquid food. Older nestlings will thrust their heads into the adult's throat and remove whole fish regurgitated into the neck pouch.

\section{Legal Status}

The U.S. Fish and Wildlife Service (USFWS) has the primary responsibility and authority for managing migratory bird populations in the U.S. This authority was established by the Migratory Bird Treaty Act (MBTA) of 1918, a treaty between the U.S. and Great Britain (on behalf of Canada) to:

- ensure the conservation and management of migratory birds internationally,

- sustain healthy migratory bird populations for consumptive and non-consumptive uses, and

- restore declining populations of migratory birds.

In 1972, the U.S. Convention with Mexico was amended, and the double-crested cormorant was added to the list of migratory birds and given protection in the U.S .under the MBTA. Under this protection, cormorants cannot be captured or shot, and their nests and eggs cannot be disturbed unless a permit is obtained from the USFWS.
Depredation permits to take cormorants have been issued by USFWS since 1986, primarily to federal, state, and tribal agencies and aquaculture producers, and may allow for the taking of adults, eggs, young, or active nests.

In March 1998, the USFWS issued an Aquaculture Depredation Order (AQDO), allowing people engaged in commercial aquaculture to shoot cormorants without a federal permit at freshwater aquaculture facilities, or stateoperated hatcheries in Minnesota and 12 southeastern states. The AQDO allowed shooting of cormorants during daylight hours when necessary to protect aquaculture and hatchery stock if these actions were taken in conjunction with a non-lethal harassment program reviewed by the USDA-APHIS-Wildlife Services (WS).

\section{USDA-APHIS Wildlife Services}

Although the USFWS has primary responsibility for managing cormorants, the USDA-APHIS-WS is the primary federal agency involved with on-the-ground management activities when cormorants cause damage. Wildlife Services helps states, organizations, and individuals resolve conflicts between people and wildlife on public and private lands by collecting information, documenting damage, and recommending or implementing options for wildlife damage management. In addition, the USDA-APHIS-WS-National Wildlife Research Center is the primary federal program

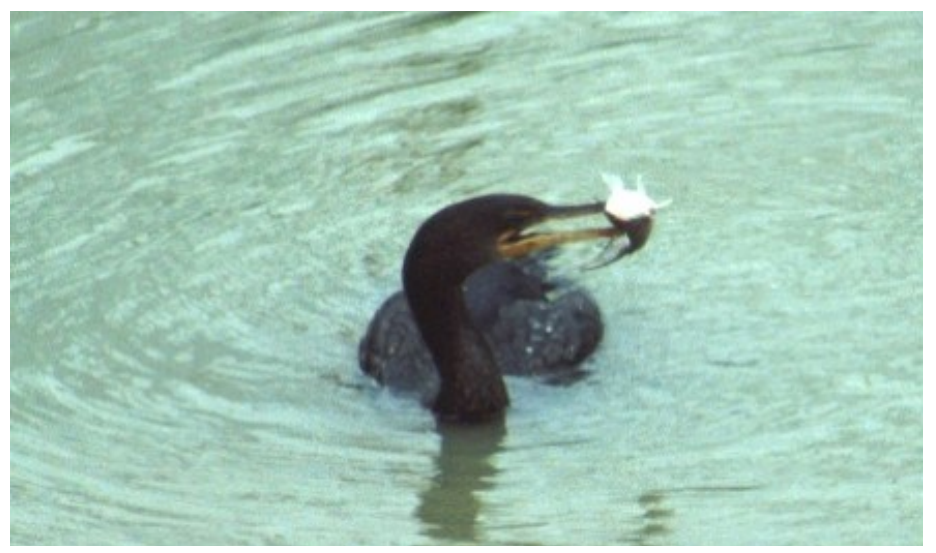

Figure 15. Double-crested cormorants feed on a variety of fish species. 
involved with research on assessment and tools and techniques associated with reducing conflicts.

\section{State Wildlife Management Agencies}

State wildlife agencies also are involved in management of double-crested cormorants. Double-crested cormorants are protected by migratory bird legislation in many states in addition to the MBTA. Cormorant control programs are being implemented in states, however, where birds are negatively affecting fish populations, vegetation, and other colonial water-birds. In New York and Vermont, programs are underway to prevent the spread of cormorants to other nesting islands in Lake Ontario, Oneida Lake, and Lake Champlain.

In 2003, the USFWS, in cooperation with WS, finalized an Environmental Impact Statement (EIS) on double-crested cormorant management to address growing concerns from the public and natural resource management professionals about the population and range expansion of the doublecrested cormorant in the U.S. and their effects on local fish populations, other bird populations (including threatened and endangered species), vegetation and habitat, private property, and economic opportunities.

\section{Increased Local Control}

The USFWS issued new regulations in August 2003 that enhanced the flexibility of management agencies to deal with problems on a more local level, while ensuring the long-term sustainability of cormorant populations. The regulations included a new Public Resource Depredation Order (PRDO) that allows state fish and wildlife agencies, federally-recognized tribes, and WS to use lethal control measures to manage double-crested cormorants to address conflicts in 24 states, including: Alabama, Arkansas, Florida, Georgia, Illinois, Indiana, lowa, Kansas, Kentucky, Louisiana, Michigan, Minnesota, Mississippi, Missouri, New York, North Carolina, Ohio, Oklahoma, South Carolina, Tennessee, Texas, Vermont, West Virginia, and Wisconsin.

According to the PRDO, lethal control, including shooting, egg-oiling or destruction, and nest destruction, can be carried out to protect public resources including fish, wildlife, plants, and other wild species on public lands and waters. With appropriate landowner permission, control activities also can take place on private lands where double-crested cormorants are causing harm to public resources. 


\section{Acknowledgements}

Figure 1. Photo by USFWS

Figure 2. Photo by Jerry Feist, USDA-APHIS-WS

Figure 3. Image by Prevention and Control of Wildlife Damage (PCWD)

Figure 4. Image courtesy of Craig Tucker, USDA, Agriculture Research Service, Warmwater Aquaculture Research Unit, Stoneville, MS

Figure 5. Photo by Bird-X, Inc.

Figure 6. Photo courtesy of the New York Department of Environmental Conservation

Figure 7. Photo by Stephen M. Vantassel

Figure 8. Photo by Elizabeth Craig

Figure 9. Photo by Tony Aderman, USDA-APHIS-WS

Figure 10. Map from The Birds of North America Online (A. Poole, Ed.). Ithaca: Cornell Lab of Ornithology

Figure 11. Photo by Charles D. Lovell, USDA-APHIS-WS

Figure 12. Photo by Donna A. Dewhurst, USFWS

Figure 13. Photo by Brian S. Dorr, USDA-APHIS-WS

Figure 14. Photo by Stan Tekiela

Figure 15 Photo by Brian S. Dorr, USDA-APHIS-WS

We thank Katie C. Hanson-Dorr and Fred C. Cunningham for their helpful comments and suggestions on an earlier version of this publication.

\section{Glossary}

Recruitment: In the fish industry, reaching a certain size or reproductive stage.

Salmonids: Fish in the family salmonidae, including salmon, trout, chars, graylings, and freshwater whitefishes.

Split-pond system: A hybrid of recirculating and pond aquaculture production

\section{Key Words}

Aquaculture, Co-nesting species, Cormorant, Doublecrested cormorant, Egg-oiling, Fisheries, Hatcheries, Nest destruction, Phalacrocorax auritus, Sportfish, Vegetation damage, Wildlife damage.

\section{Disclaimer}

Wildlife can threaten the health and safety of you and others in the area. Use of damage prevention and control methods also may pose risks to humans, pets, livestock, other non-target animals, and the environment. Be aware of the risks and take steps to reduce or eliminate those risks.

Some methods mentioned in this document may not be legal, permitted, or appropriate in your area. Read and follow all pesticide label recommendations and local requirements. Check with personnel from your state wildlife agency and local officials to determine if methods are acceptable and allowed.

Mention of any products, trademarks, or brand names does not constitute endorsement, nor does omission constitute criticism. 


\section{Resources}

Cornell University Cooperative Extension Wildlife Control Information Website. http://wildlifecontrol.info/ Accessed October 27, 2014.

Dorr, Brian S., J. J. Hatch and D. V. Weseloh. 2014. Double-crested cormorant (Phalacrocorax auritus), The Birds of North America Online (A. Poole, Ed.). Ithaca: Cornell Lab of Ornithology.

http://bna.birds.cornell.edu/bna/species/441/articles/introduction Accessed October 27, 2014.

USDA-APHIS, Wildlife Services, National Wildlife Research Center.

http://www.aphis.usda.gov/wps/portal/aphis/ourfocus/wildlifedamage?1dmy\&urile=wcm\%3apath\%3a\%2FAPHIS_Conte nt_Library\%2FSA_Our_Focus\%2FSA_Wildlife_Damage\%2FSA_Programs\%2FSA_NWRC Accessed October 27, 2014.

US National Cooperative Extension website (eXtension). http://extension.org Accessed October 27, 2014.

The Internet Center for Wildlife Damage Management. http://ICWDM.org Accessed October 27, 2014.

National Wildlife Control Training Program. http://nwctp.com Accessed July 27, 2015. 


\section{Appendix}

Damage Management Methods for Double-crested Cormorants

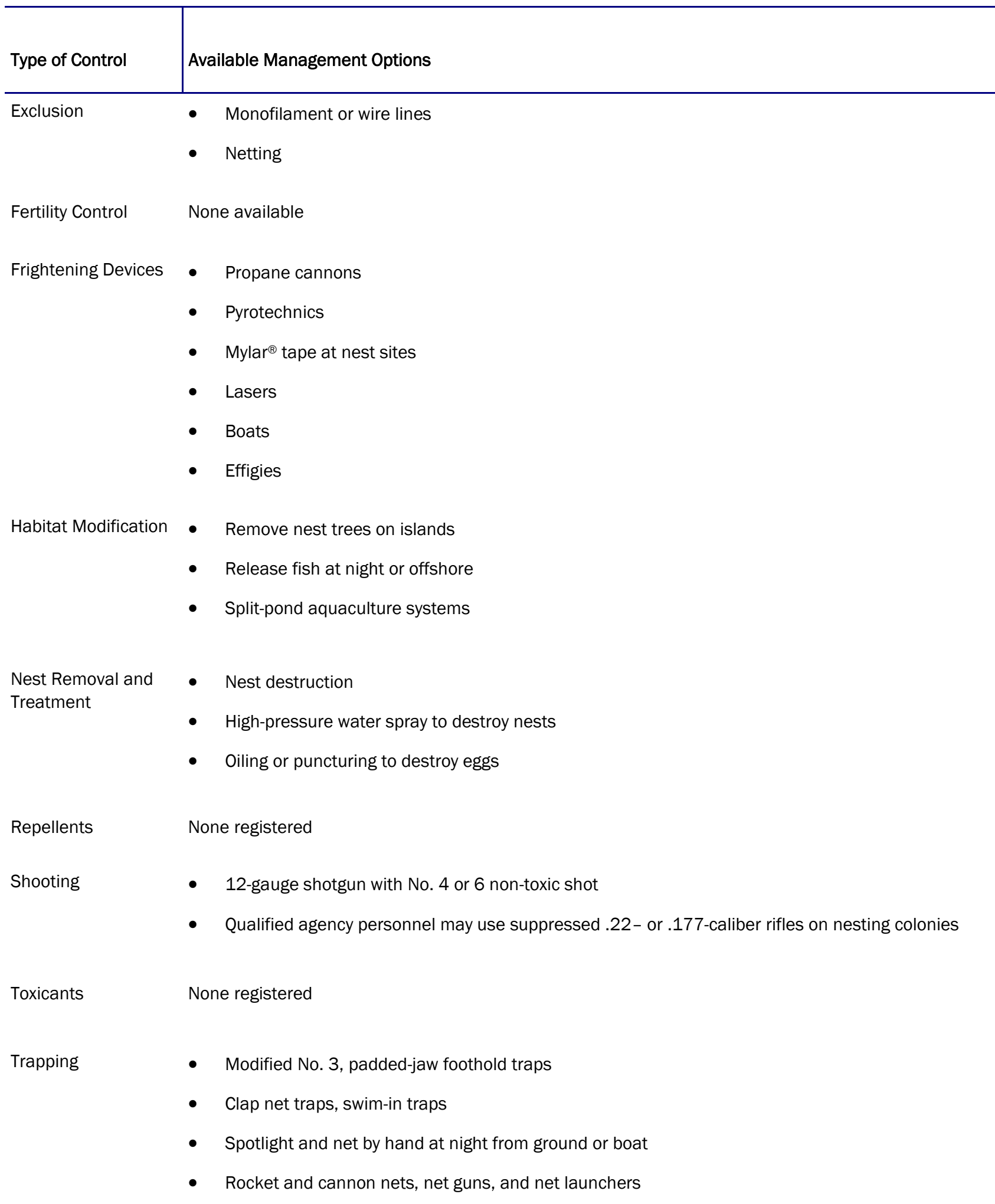

